\title{
Major Trauma and Severe Burn: A Synergistic Mortality. Case Report and Literature Review
}

\section{Traumatismo grave y quemadura severa: una mortalidad sinérgica. Reporte de un caso y revisión bibliográfica}

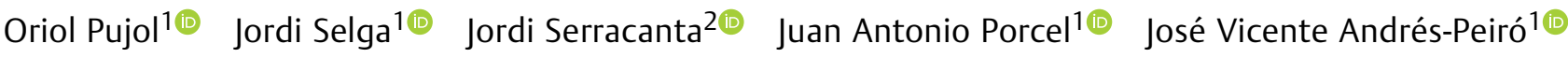 \\ ${ }^{1}$ Trauma Unit, Department of Traumatology and Orthopedic Surgery, \\ Hospital Universitari Vall d'Hebron, Universitat Autònoma de \\ Barcelona, Barcelona, Spain \\ 2 Burn Unit, Department of Plastic Surgery, Hospital Universitari Vall \\ Address for correspondence Oriol Pujol, MD, Servei de Cirurgia \\ Ortopèdica i Traumatologia, Hospital Universitari Vall d'Hebron, \\ Universitat Autònoma de Barcelona, Barcelona, Spain \\ (e-mail: oriolp-6@hotmail.com).
} d'Hebron, Universitat Autònoma de Barcelona, Barcelona, Spain

Rev Chil Ortop Traumatol 2020;61:23-27.

\begin{abstract}
Keywords

- burn

- fracture

- polytrauma

- combined injury

- soft tissue
\end{abstract}

Resumen
Case Presentation A 42-year-old man was transferred to our institution after a highenergy accident (an explosion). He presented second-degree burns on $20 \%$ of the total body surface area (TBSA), affecting the lower hemiabdomen and the lower right limb. He also presented a supraintercondylar open fracture of the right femur (Gustilo I). The burns were treated with debridement and coverage with mesh graft, while the fracture required an early transitory transarticular external fixation with delayed definitive osteosynthesis. Our patient presented good local and systemic evolution. We can offer a eleven-month follow-up.

Discussion The literature supports that the combination of trauma and burn injuries is a relatively rare pattern, which may explain the lack of knowledge and studies on this subject. This double injury has demonstrated a synergistic effect on mortality. The management of soft tissues in the coexistence of an open fracture and a burn in the same limb is a challenge. The method and timing of the treatment of the fracture directly impacts the treatment of the burn (and vice versa), and most authors tend to treat the fracture first. All of the studies reviewed emphasized the importance of the multidisciplinary approach.

Conclusions We have presented a complex case combining major trauma and severe burns. Although there is a lack of studies in the literature on this subject, the papers state that this is an unusual pattern with a synergistic effect on mortality. In our experience, the management of soft tissues and the multidisciplinary approach play a central role, as it is also stated in the literature. The management of these patients is still controversial, and more studies are needed.

Presentación del Caso Hombre de 42 años trasladado a nuestra institución tras un accidente de alta energía (explosión). Presentaba quemaduras de segundo grado del $20 \%$ de la superficie corporal total (SCT), afectando el hemiabdomen inferior y la extremidad inferior derecha. También presentaba una fractura abierta supraintercondílea de fémur received

January 16, 2020

accepted

March 2, 2020
DOI https://doi.org/

10.1055/s-0040-1709984. ISSN 0716-4548.
Copyright (@) 2020 by Thieme Revinter

Publicações Ltda, Rio de Janeiro, Brazil
License terms

(ㄷ) (i) $\ominus$ (\$) 
derecho (Gustilo I). Las quemaduras fueron tratadas mediante desbridamiento y cobertura mediante injerto mallado, mientras que la fractura requirió un fijador externo transarticular precoz de forma transitoria con una osteosíntesis definitiva diferida. Nuestro paciente presentó buena evolución local y sistémica. Podemos ofrecer un seguimiento a 11 meses. Discusión La bibliografía defiende que la lesión combinada de traumatismo y quemadura es un patrón relativamente raro, pudiendo explicar la falta de conocimiento y publicaciones al respecto. Este doble insulto ha demostrado un efecto sinérgico en la mortalidad. El manejo de las partes blandas cuando coexisten una fractura abierta y una quemadura en la misma extremidad es un desafío. El método y el momento de tratamiento de la fractura impactan de forma directa en el tratamiento de la quemadura (y viceversa); y la mayoría de los autores tienden a tratar en primer lugar la fractura. Todos los estudios analizados enfatizan la importancia del abordaje multidisciplinario.

\author{
Palabras clave \\ - quemadura \\ - fractura \\ - politrauma \\ - lesión combinada \\ - partes blandas
}

Conclusiones Hemos presentado un caso complejo combinando traumatismo grave y quemaduras severas. Aunque haya una falta de bibliografía, los estudios afirman que se trata de un patrón inusual con un efecto sinérgico sobre la mortalidad. En nuestra experiencia, el manejo de las partes blandas y el abordaje multidisciplinario tienen un rol central, tal y como defienden también los artículos publicados. El manejo de estos pacientes sigue siendo controvertido, y son necesarios más estudios.

\section{Case Presentation}

\section{Medical History}

A 42-year-old man was transferred to our institution with major trauma and severe burns after a high-energy accident (a boiler explosion). He did not present relevant diseases or known allergies.

Primary and secondary surveys were performed coordinating anesthesia, traumatology, plastic surgery, intensive care and nursing. The patient was hemodynamically stable, eupneic and conscious (Glasgow 15). Second-degree burns on $20 \%$ of the total body surface area (TBSA) affecting the lower hemiabdomen and the lower right limb were diagnosed. No signs of inhalation or circumferential burns were present. Moreover, his right knee presented tumefaction, functional impotence, and a punctiform wound ( - Fig. 1). The body's total antioxidant capacity the full-body CT scan (skull, cervical, chest, abdomen and pelvis) and the blood test were not pathologic, but the X-ray of the right knee showed a supraintercondylar fracture of the femur ( $\mathbf{- F i g . 2}$ ). Therefore, due to these lesions, his injury severity score (ISS) was 18.

\section{Management}

After the irrigation of the wounds with saline and the administration of prophylactic antibiotics (following the protocol of our institution: amoxicillin-clavulanic acid $2 \mathrm{~g} /$ $8 \mathrm{~h}$ and gentamicin $240 \mathrm{mg} / 24 \mathrm{~h}$ intravenously during 3 days) and a dose of the tetanus vaccine, an urgent surgery was performed. In this initial surgery, we debrided the open wound, and a transarticular external fixation was implanted (-Fig. 1). Therefore, multiple aggressions to soft tissues coexisted in the same limb: an open-joint fracture (Gustilo I), burns, percutaneous devices, and blunt trauma.
The patient was admitted to the burn unit and underwent monitoring, saline therapy and periodic topic care. Nine days later, when the patient was stable and the soft tissues were in acceptable conditions, the delayed definitive surgery for the fracture was performed. This surgery consisted of an open reduction and internal fixation (ORIF) with two cannulated screws in the intercondylar trace and an anatomical compression plate in the supracondylar trace (-Fig. 3). It was necessary to carry out a non-habitual approach (anterior) to

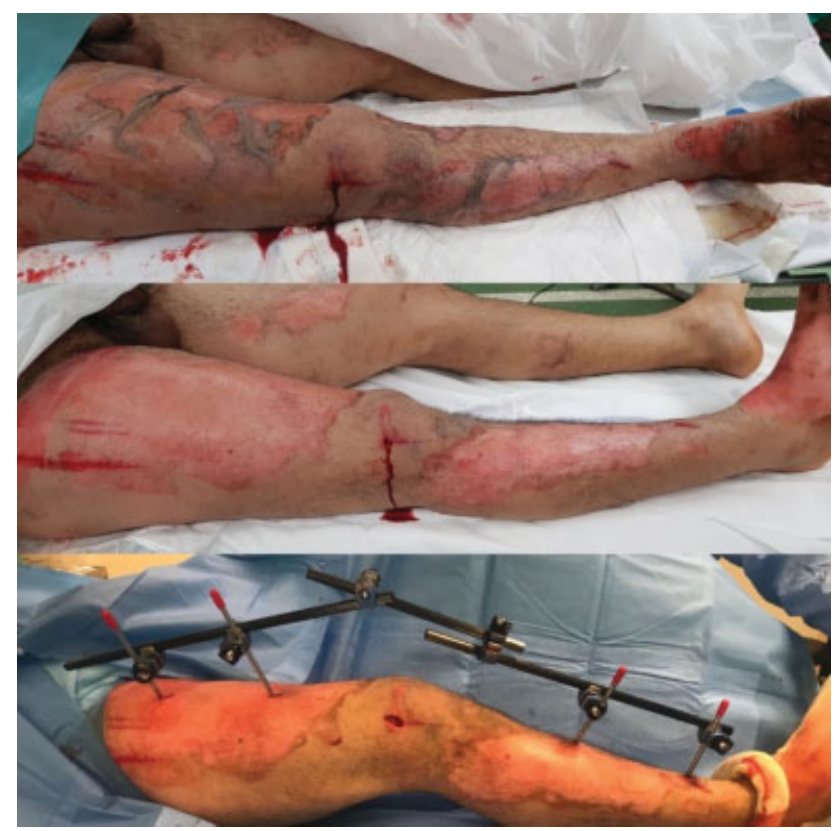

Fig. 1 Second-degree burn on the lower right limb and open fracture (Gustilo I). 


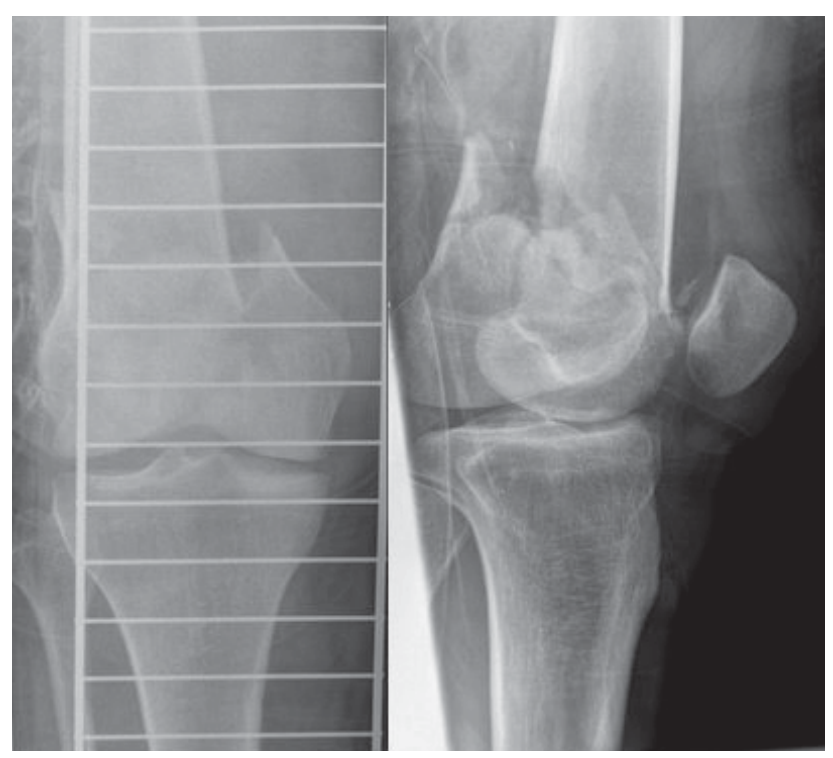

Fig. 2 X-ray images showing the supraintercondylar fracture.

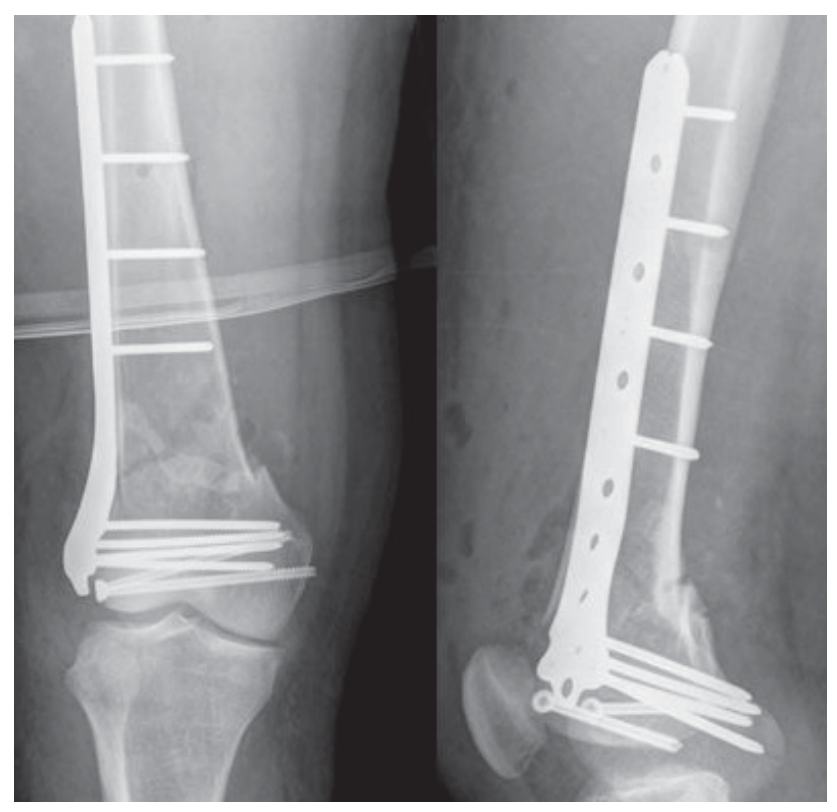

Fig. 3 Postoperative X-ray images showing the osteosynthesis of the fracture.

manage the soft tissues and to include the open wound into the incision (-Fig. 4).

Eighteen and thirty days after the accident, the patient underwent two plastic surgeries to treat the regions of the body with deep second-degree burns, consisting of debridement and coverage with mesh grafts.

After the surgeries, intensive non-weight-bearing physiotherapy to recover joint balance and strength was planned.

\section{Outcomes}

Our patient presented good local and systemic evolution, and 35 days after the accident he was discharged. During the rehabilitation, his joint balance $\left(0^{\circ}-80^{\circ}\right)$ and strength (2-3/5) had significantly improved, and he was able to walk without bearing weight.

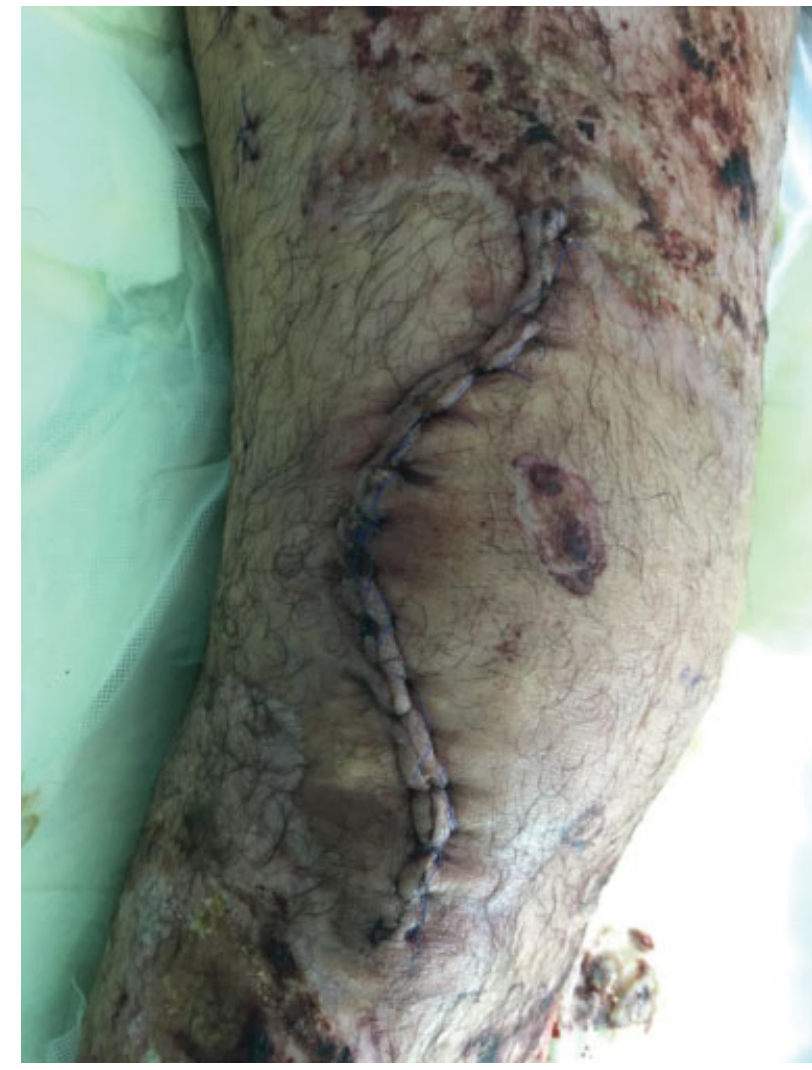

Fig. 4 Incision used in the surgery to manage the soft tissues and to include the open wound.

After a follow-up of eleven months, the clinical evolution remained satisfactory. The surgery wound and the burns had healed. The joint balance of the knee was $0^{\circ}-110^{\circ}$, and the strength was 4-5/5 (physiotherapy had been maintained). He walked with total weight-bearing without presenting pain, and his functional Knee Society Score (KSS) was excellent $(85 / 100)$. The X-ray images showed complete consolidation.

\section{Discussion}

We have presented a case of a patient with a combination of major trauma and severe burn. The literature supports that this combination of injuries is relatively rare. Santaniello et al ${ }^{1}$ published a retrospective review (1990-2000) of a 10-year experience of a single trauma and burn center in Illinois in which 24,093 patients were identified. In total, 22,284 (92.5\%) of them presented only trauma injuries, 1,717 (7.1\%) had only burn injuries, and 92 had combined injuries ( $0.4 \%$ of the total). Battaloglu et al, ${ }^{2}$ in a retrospective review (2010-2016) based on the National Trauma Registry for England and Wales, found 188 patients with concomitant burn and trauma injuries. And Hawkings et $\mathrm{al}^{3}$ published another retrospective review based on the National Trauma Data Bank of America (1994-2002) in which they found 411,173 patients only with trauma injuries, 7,324 only with burns, and 5,462 with a combination of both (the prevalence was of $1.23 \%$ ). The information regarding the aforementioned retrospective reviews is shown in - Table 1. 
Table 1 Comparative table showing the retrospective reviews included in the present study that have studied the combined burn and trauma injuries

\begin{tabular}{|c|c|c|c|c|c|c|c|c|}
\hline \multirow[t]{2}{*}{ Article } & \multirow[t]{2}{*}{$\mathrm{N}^{\circ}$ of patients } & \multirow{2}{*}{$\begin{array}{l}\text { Prevalence of } \\
\text { burn-trauma } \\
\text { patients }\end{array}$} & \multicolumn{3}{|c|}{$\begin{array}{l}\text { Mortality (percentage and rela- } \\
\text { tive risk [RR]) }\end{array}$} & \multicolumn{3}{|c|}{ Lenght of Stay } \\
\hline & & & $\begin{array}{l}\text { Burn- } \\
\text { Trauma }\end{array}$ & Burn & Trauma & $\begin{array}{l}\text { Burn- } \\
\text { Trauma }\end{array}$ & Burn & Trauma \\
\hline Santaniello et al ${ }^{1}$ & 24.093 & $0.38 \%$ & $28.3 \%$ & $\begin{array}{l}9.8 \% \\
\text { (RR: 2.89) }\end{array}$ & $\begin{array}{l}4.3 \% \\
\text { (RR: 6.58) }\end{array}$ & 18 days & 13.7 days & 5.3 days \\
\hline Battaloglu et al $\left.\right|^{2}$ & $\begin{array}{l}\text { compilation of } \\
188 \text { patients }\end{array}$ & $100 \%$ & $23.4 \%$ & $\begin{array}{l}18.6 \% \\
\text { (RR: } 1.26)\end{array}$ & $\begin{array}{l}6.8 \% \\
\text { (RR: } 3.44)\end{array}$ & 12 days & 8 days & 9 days \\
\hline $\begin{array}{l}\text { Hawkings et al } \\
\text { (results also } \\
\text { compared by } \\
\text { stratified severity) }\end{array}$ & 423.959 & $1.23 \%$ & $11.2 \%$ & $\begin{array}{l}3 \% \\
\text { (RR: } 3.73)\end{array}$ & $\begin{array}{l}5.3 \% \\
\text { (RR: } 2.11)\end{array}$ & - & - & -- \\
\hline
\end{tabular}

This low incidence may explain the lack of knowledge and studies about these combined injuries. Before these three big retrospective reviews, only one article with a large number of patients was found: the classic article 4 by Purdue and Hunt (1989) studying 176 patients. However, other articles with a lower number of patients or case reports were found. ${ }^{5-7}$

The combination of these two injuries has demonstrated a synergistic effect on mortality. Santaniello et $\mathrm{al}^{1}$ found a mortality of $28.3 \%$ in this group of patients, compared with 9.8\% among the burned patients, and $4.3 \%$ among the patients with trauma injuries (relative risk [RR]: 2.89 and 6.58 respectively). Moreover, an increased length of stay was observed (18 days versus 13.7 and 5.3 respectively). The combined group had no difference in TBSA compared with the burned group, but it had an increased ISS when compared with the trauma group. Similar results were found by Battaloglu et $\mathrm{al}^{2}$ : an increased mortality (23.4\% for the combined group, $18,6 \%$ for the burned group, and $6,8 \%$ for the trauma group, and RRs of 1.26 and 3.44 respectively) and length of stay (12 days versus 8 days and 9 days respectively).

This effect of this double injury was also found in the study by Hawkings et al. ${ }^{3}$ In this article, the mortality was of $11.2 \%$ for the combined group, which was significantly higher than that of the burned group (3\% and RR of 3.73) and the trauma group (5.3\% and RR of 2.11). The most interesting fact about this study was that the results were stratified and compared by level of trauma and burn severity. In cases of both minor- and majorseverity injuries, a statistically significant increase in mortality was found in the combined group.

An important item in our case report was the coexistence of an open fracture and a burn on the same limb. In addition, there was a blunt trauma caused by the explosion, as well as the percutaneous devices of the external fixation. Consequently, the management of soft tissues was challenging.

Despite the little information found in the literature, we highlight the article by Bradshaw et al. ${ }^{8}$ They studied 22 patients with collocated burn and fracture injuries. In total, 17 patients were submitted to operative management ( 11 with internal fixation, 2 with external fixation, and 4 with temporary external fixation and delayed internal fixation after an average of 3 to 4 days), and 5 were submitted to non-operative management. There were nine complications (all in the operated group), and five of them were infections (all in the internal fixation group). The authors concluded that the method and timing of the treatment of the fracture directly impacts the treatment of the burn (and vice versa). In cases of collocated injuries, the optimum management is still controversial. Most authors tend to treat the fracture first.

Since percutaneous surgery is respectful of soft tissues, it could be especially adequate in this scenario. Although it is possible to reduce a fracture using this minimally invasive approach, it is normally used when fractures have an acceptable displacement.

In our patient, we decided to completely treat the fracture before the burns. The objectives were: 1) to stabilize the patient; 2) to enable early mobilization; and 3) to simplify the management of the soft tissues. In the treatment of the fracture, we first used temporary external fixation, which was implanted during the damage-control surgery (DCS). The external fixation device enabled us to stabilize the bone and soft tissues rapidly and at a distance from the fracture, avoiding a second hit in a polytraumatic patient. The DCS is a therapeutic strategy consisting of a staged surgical approach in the critically-injured trauma patient (Breederveld and Kreis ${ }^{9}$ studied the DCS in the burned patient, for example). The complex definitive surgery (ORIF) was delayed for nine days until the patient was stable and the condition of the soft tissues had improved. As he presented a displaced articular fracture, we decided not to use a percutaneous approach. Once the bone treatment had ended, the regions of the body with deep second-degree burns were surgically treated with debridement and coverage with mesh grafts.

Finally, it is remarkable that all of the studies reviewed emphasized the importance of the multidisciplinary approach. ${ }^{1-8}$ It is thought that the improvement in the management of these patients is due to the advances in critical, trauma and burn care and their orchestration.

\section{Conclusions}

We have presented a complex case combining major trauma and severe burns. The supraintercondylar open fracture was 
treated with early transitory external fixation and delayed definitive ORIF, while the burns required debridement and coverage with mesh grafts. Our patient presented good local and general evolution.

Although there is a lack of studies in the literature, the papers state that this is an unusual pattern with a synergistic effect on mortality. In our experience, the management of soft tissues and the multidisciplinary approach play a central role, as it is also stated in the literature. The management of these patients is still controversial, and more studies are needed.

\section{Conflict of Interests}

The authors have noconflict of interests to declare.

\section{References}

1 Santaniello JM, Luchette FA, Esposito TJ, et al. Ten year experience of burn, trauma, and combined burn/trauma injuries comparing outcomes. J Trauma 2004;57(04):696-700, 700-701
2 Battaloglu E, Fragoso Iniguez M, Lecky F, Porter K. Incidence of combined burns and major trauma in England and Wales. J Trauma 2018;22(01):51-55

3 Hawkins A, Maclennan PA, McGwin G Jr, Cross JM, Rue LW III. The impact of combined trauma and burns on patient mortality. J Trauma 2005;58(02):284-288

4 Purdue GF, Hunt JL. Multiple trauma and the burn patient. Am J Surg 1989;158(06):536-539

5 Cairns BA, Stiffler A, Price F, Peck MD, Meyer AA. Managing a combined burn trauma disaster in the post-9/11 world: lessons learned from the 2003 West Pharmaceutical plant explosion. J Burn Care Rehabil 2005;26(02):144-150

6 Rosenkranz KM, Sheridan R. Management of the burned trauma patient: balancing conflicting priorities. Burns 2002;28(07):665-669

7 Varghese TK, Kim AW, Kowal-Vern A, Latenser BA. Frequency of burn-trauma patients in an urban setting. Arch Surg 2003;138 (12):1292-1296

8 Bradshaw L, Wasiak J, Cleland H. Is operative management of fractures safe in the collocated burn and fracture injury? Injury 2015;46(06):1145-1149

9 Breederveld RS, Kreis RW. Damage control in burn surgery. Br J Surg 2009;96(11):1227-1228 